\title{
Microbial Fertilizer Seed Coating Effect on Different Soybean (Glycine Max L.) Varieties Growth Yield and Quality in Altınekin (Konya) Ecological Conditions
}

\author{
Nurgül Kıtır Şen ${ }^{1 *}$ \\ 1* Gebze Teknik University, Institute of Earth and Marine Sciences, Kocaeli, Turkey, (ORCID: 0000-0001-7463-4186), nksen@gtu.edu.tr
}

(First received 8 July 2021 and in final form 9 September 2021)

(DOI: 10.31590/ejosat.966424)

ATIF/REFERENCE: Kitır Sen, N. (2021). Microbial Fertilizer Seed Coating Effect on Different Soybean (Glycine Max L.) Varieties Growth Yield and Quality in Altınekin (Konya) Ecological Conditions. European Journal of Science and Technology, (27), 459-465.

\begin{abstract}
It has been observed in many studies that microbial fertilizers increase the efficiency of plant quality and productivity. The use of microbial fertilizers as seed biofilm coating agents is a new process. Since soybean is a very sensitive crop, it needs special conditions in order to achieve a viable productivity in its cultivation. In this study, seed biofilm coating applications were carried out on two different local soybean cultivars called Ilksoy and Ceysoy of the effect of PGPR-based microbial consortium (Bacillus subtillis, Bacillus megaterium and Lactococcus spp.). Nitrogen $\left(\mathrm{N}_{2}\right)$ stabilizer and phosphate $\left(\mathrm{PO}_{4}\right)$ solubilizing microorganisms were used. Seed coating systems are often used for the protection of seeds, but the use of feeding has not become widespread. Good nutrition is essential for the future growth period and quality of the crop, from seed planting to the seedling development period. In areas where conventional farming is practiced, fertilization is often not given sufficient attention due to the tedious application and cost. Therefore, seed coating may be an alternative solution to reduce fertilization application times, quantities and costs. Based on this perception, the study was conducted in Altınekin, Konya, which is known as a semi-arid and mostly traditional agricultural region. An alternative product potential for agriculture in semi-arid regions, microbial fertilizer seed coatings and native soybean varieties (Ilksoy and Ceysoy) were investigated in Altınekin (Konya). Some growth, yield and quality contents of soybean were determined by this study. The fieldwork was carried out in the Altınekin, Konya region according to the random block field experiment design. The productivity and physical properties of soybean were tested and the oil content of soybean seeds was analyzed by Near Infrared Spectrometry (NIRS). According to the results obtained, the effect of seed coating application on yield increase was statistically significant at the $\mathrm{p}<0.01$ level. In addition, statistically significant effects of cultivar and bacterial application interaction on yield increase were found.
\end{abstract}

Keywords: Soybean, Microbial fertilizer, Seed coating, Yield, Quality.

\section{Altınekin (Konya) Ekolojik Koşullarında Yetiştirilen Farklı Soya (Glycine Max L.) Çeşitlerinde Mikrobiyal Gübre Tohum Kaplamasının Verim ve Kalite Unsurlarına Etkisi}

$\ddot{O} \mathbf{z}$

Mikrobiyal gübrelerin bitki kalitesi ve üretkenliği üzerindeki verimliliğini artırdığı yapılan bir çok çalışmada gözlemlenmiştir. Mikrobiyal gübrelerin tohum biyofilm kaplama ajanı olarak kullanılması yeni bir prosestir. Soya fasulyesi çok hassas bir ürün olduğundan yetiştiriciliğinde uygulanabilir bir verimlilik elde etmek için özel şartlara ihtiyaç duyar. Bu çalışmada, PGPR bazlı mikrobiyal konsorsiyum (Bacillus subtillis, Bacillus megaterium ve Lactococcus spp.) etkisinin, Ilksoy ve Ceysoy olarak adlandırılan iki farklı yerel soya çeşidi üzerinde tohum biyofilm kaplama uygulamaları yapılmıştır. Soya fasulyesi tohum döneminde besleme etkinliklerini görmek için biyofilm tohum kaplamasında için azot $\left(\mathrm{N}_{2}\right)$ sabitleyici ve fosfat $\left(\mathrm{PO}_{4}\right)$ çözündürücü mikroorganizmalar

* Corresponding Author: nksen@gtu.edu.tr 
kullanılmıştır. Tohum kaplama sistemleri genellikle tohumların korunması için kullanılır, ancak besleme kullanımı yaygınlaşmamıştır. Ürünün gelecekteki büyüme dönemi ve kalitesi için tohum ekiminden fide gelişim periyoduna kadar iyi bir besleme şarttır. Konvansiyonel tarım yapılan bölgelerde, meşakkatli uygulama ve maliyet nedeniyle çoğunlukla gübrelemeye yeterli önem verilmemektedir. Bu nedenle tohum kaplaması, gübreleme uygulama sürelerini, miktarlarını ve maliyetini azaltmak için alternative bir çözüm olabilir. Bu algıdan yola çıkarak, çalışma yarı kurak ve çoğunlukla geleneksel tarım bölgesi olarak bilinen Altınekin, Konya'da yapılmıştır. Yarı kurak bölgelerde tarım için alternatif bir ürün potansiyeli, mikrobiyal gübre tohum kaplamaları ile yerli soya fasulyesi çeşitleri (İlksoy ve Ceysoy), Altınekin (Konya) bölgesinde incelenmiştir. Soya fasülyesinde bazı gelişim verim ve kalite içerikleri bu çalışma ile tespit edilmiştir. Saha çalışması Altınekin, Konya bölgesinde tam şansa bağlı tesadüf blokları tarla deneme desenine göre yapılmıştır. Soya fasulyesinin üretkenliği ve fiziksel özellikleri test edilerek ve soya fasulyesi tohumlarının yağ içeriği Near infrared spektrometre (NIRS) ile analiz edilmiştir. Elde edilen sonuçlara göre tohum kaplama uygulamasının verim artışına etkisi istatistiksel olarak p <0.01 düzeyinde anlamlı bulunmuştur. Ayrıca çeşit ve bakteri uygulama interaksiyonunun da verim artışı üzerinde istatiksel olarak önemli etkileri bulunmuştur.

Anahtar Kelimeler: Soya, Mikrobiyal gübre, Tohum kaplama, Verim, Kalite.

\section{Introduction}

Soybean is known as one of the crucial oil crops all over the world (Ibrahim, 2015). Soybean (Glycine max L.), which is summer and annual plant, has been the most valuable food source of Far East countries such as China and Korea for nearly 4500 years. Soybean is also known as the wonderful plant of the century, has an important place in human and animal nutrition since it contains $18-24 \%$, oil $36-40 \%$ protein, $26 \%$ carbohydrate and $8 \%$ mineral substances in its seeds. Due to the nutrients it contains, soybeans are used in more than 250 different places. Soy oil, which is fragrant and yellow in color; since it contains fatty acids that regulate fat and lipid metabolism in the human, it is of great importance in the nutrition of people with vascular stiffness, diabetes and coronary heart disease. An important feature of soybean oil is that it has an anti-narrowing effect. Since soybean oil has $\mathrm{Ca}, \mathrm{Fe}, \mathrm{Zn}$ elements, $\mathrm{B}$ and $\mathrm{E}$ vitamins, it has an important place in human nutrition (Altınyüzük, 2017). The initial farming of Soybean in Turkey has started in 1940, Blacksea region. The farming of wheat as the main product, then soy cultivation as the second product has been started in 1975, Cukurova (Arığlu, 2007).

Seed coating is a common application in Soybean due to its sensitive seed. In a study it has been confirmed that coating with phosphorus fertilizer of Soybean seed increases productivity due to the phosphorus dosage and source. In the form of phytic acid of phosphorus seed coating application to soybean was increased soybean yield in $14 \%$ in the grain total mass (Peske, Baudet, \& Peske, 2009). Rhizobial inoculants has been used for seed coating for increasing $\mathrm{N}_{2}$ fixation on soybean seeds correlated the inoculation performance has been varied in a high ratio (Dobereiner, Urquiaga, \& Boddey, 1995; Kubota, Hoshiba, \& Bordon, 2008; Peoples \& Craswell, 1992). The common idea of using phosphate solubilizing microorganisms to increase the existing phosphorus intake and reduce the fertilizer usage in the soil (Fernández, Zalba, Gómez, \& Sagardoy, 2007; Illmer \& Schinner, 1992). Soil is the isolation source of most of the phosphate solubilizing bacteria like Bacillus, Psudomonas, Rhizobium, Micrococcus etc. (Fernández et al., 2007; Rodríguez \& Fraga, 1999).

The aim of this study to see the growth potential of some domestic varieties of soybean in Altınekin (Konya region) as semiarid climate condition as an alternative product for rotation and to see the microbial seed coating nutrition efficiency of soybean on product yield and quality.

\section{Material and Method}

\subsection{Field Conditions}

The present study was carried out in field conditions Beta Ziraat ve Ticaret Inc., in Turkey, Konya, Altınekin region between 2018-2019. Altınekin is located at 38.2989 N, $32.8792 \mathrm{E} ; 1080 \mathrm{~m}$ altitude. Average yearly precipitation (1988-2018) is $404.9 \mathrm{~mm}$, which is regarded semiarid climate. The mean temperatures, mean relative humidity and total precipitation average values during growing period (April-October) were $19.45^{\circ} \mathrm{C}, 47.81 \%$, and $27.32 \mathrm{~mm}$, respectively in 2018 . The experimental area soil was aridisol according to the U.S. soil taxonomy.. Soil $\mathrm{pH}$ was 7.95, EC $0.26 \mathrm{mmhos} / \mathrm{cm}$ organic matter $1.79 \%$, CaCO3 $66.34 \%$, total $\mathrm{N} 0.0093 \%$, exchangeable $\mathrm{CaCO}_{3} 2069 \mathrm{mg} \mathrm{kg}^{-1}, \mathrm{Mg} 251 \mathrm{mg} \mathrm{kg}$ ${ }^{1}, \mathrm{~K}_{2} \mathrm{O} 124.3 \mathrm{mg} \mathrm{kg}^{-1}$, Na $118.35 \mathrm{mg} \mathrm{kg}^{-1}$, plant-available P 10.88 $\mathrm{mg} \mathrm{kg}{ }^{-1}$, available Fe $1.74 \mathrm{mg} \mathrm{kg}^{-1}, \mathrm{Mn} 5.72 \mathrm{mg} \mathrm{kg}^{-1}, \mathrm{Zn} 1.062$ $\mathrm{mg} \mathrm{kg}{ }^{-1}, \mathrm{Cu} 0.602 \mathrm{mg} \mathrm{kg}^{-1}$.

\subsection{Microbial Fertilizer Seed Coating}

A commercial product which isolates are provided by Yeditepe University called 'Bactoboost' was used for soybean seed coating in this study. This product is in a dense liquid form and includes Bacillus megaterium, Bacillus subtilis, Lactococcus spp. The total living organisms amount is $1 \times 10^{6} \mathrm{cfu} / \mathrm{ml} .50 \mathrm{ml}$ product was mixed with $100 \mathrm{ml}$ water and was inoculated on soybean seeds with a seed coating machine Centricoater CC150 for 3 minutes then we left them to dry for 15 minutes.

\subsection{Field Trials}

The experiment was arranged as a completely randomized block design including seed coating formulation composed from three different microorganisms and one control without seed coating application for each soybean variety as İlksoy and Ceysoy. It was repeated for 12 rows and for each row 9 plant was taken for analysis and totally 108 plant were used for a group. Seedlings were planted in unused arable land, weeding was done by hand when required, and any chemical pesticides or fertilizers not used. Plants were adequately irrigated to prevent water stress. The sowing date is 6th of April 2018 and harvesting date is 20th of October 2018. Seeding was made with sowing machine to the field. Parcel area between row and within row were $70 \mathrm{~cm}, 8.3$ $\mathrm{cm}$, respectively.

\subsection{Yield and Quality Analysis}

The yield analysis as plant height, number of bean in a soybean plant, total grain number for each plant, plant total grain weight were measured. The oil content of soybean seeds have 
been analysed with Near-infrared Spectrometer (NIRS). For protein analysis, Kheldahl N Protein Analysis Device were used and as method TS 1620 TS 1748 ISO 937 TS EN ISO 8968-1 was used.

\subsection{Statistical Analysis}

The Data were evaluated by SAS, Minitab 19, SPSS 25 Statistical Package Program.

\section{Results and Discussion}

The varience analyses of obtained results from the seed coating application on Ilksoy and Ceysoy soybean plant varieties were given on Table 1. As can be seen in the table, the differences between the cultivars in plant height, seed weight per plant and oil per plant were found to be statistically significant at the $\mathrm{p}<0.01$ level. In terms of bacteria application, the effect of bacterial application was determined as very important $(\mathrm{p}<0.01)$ in terms of the number of pods in the plant and the total number of seeds and weight in the plant. Variety $\mathrm{x}$ bacteria interaction was found at the level of $1 \%$ in the number of pods in the plant at the height of the plant, while it was determined as $5 \%$ in the total grain weight of the plant (Table 1). Another event that can be understood from the table; while the genotypic potential gains importance in plant height and oil ratio; The number of pods per plant, the total number of grains per plant and the weight of bacteria were found to be more effective than genotypic performance. As a matter of fact, the genotype $\mathrm{x}$ environment interaction, which was determined as important in plant height, number of pods per plant and total grain weight in the plant, shows how effective the bacterial application is as an environmental effect. The expression of the effect of the bacteria applied on the Illksoy and Ceysoy cultivars in terms of average values in terms of different yield and quality factors in soybean is given in Table 2. Although plant height is under the influence of genotypeenvironment interaction, the genotypic effect was found to be higher than the environment in our study. The significant difference in plant height in cultivars was due to genotypic differences. Studies have already shown that plant height is shaped between genotypic capacity and environmental stress and varies depending on the effect size of both factors (Büyük, Soydam-Aydın, Aras, \& Biyoloji, 2012). In our study, although the plant height obtained from Ceysoy is higher than that obtained from Ilksoy, the bacterial genotype interaction was determined to be important because the effect of the bacterium was higher in Ceysoy variety and the bacterium reduced the plant height in İlksoy variety.

In soybean, pod number is one of the plant factors affecting yield and it is an important element in determining the number of grains and grain weight in the plant (Pekşen \& Gülümser, 2005). Therefore, increasing the pod number in soybean up to a certain optimum has a positive effect on yield. On the other hand, pod number is widely affected in environmental conditions and agronomic applications. The fact that it has a greater effect than the capacity is an indication that the pod number is highly affected by environmental conditions. In our study, the effect of bacteria application is approximately $30 \%$ more than the control $(91,35)$, which shows how large the effect of bacterial application is. The number of plants is very important in determining the yield together with other yield elements, and this element is significantly affected by the environment, as in the number of pods. This element, which is more sensitive to agronumic applications, is also influenced by the nutrient status in the soil. e-ISSN: 2148-2683
Therefore, both genotypic and environmental factors affect the number of seeds in the plant. Many studies have revealed that environmental effects are more evident in determining the number of grains in the plant than the genotypic effect (Baresel, Zimmermann, \& Reents, 2008). Again, studies have shown that environmental effects have a similar effect on genotypes, that is, genotypes are affected by the environment at similar rates. Similarly, in our study, the value obtained from the bacterial application was determined to be statistically significantly higher than the control. In our study, the total grain weight of the plant was found to be significant at the level of $1 \%$ in terms of genotypes bacteria application and genotype $\mathrm{x}$ bacteria interaction. Bacteria application provided a significant grain weight production compared to the control, but Ceysoy was the variety with higher grain weight than the first line. Again, the difference in grain weight between the bacteria and the control group for Ceysoy was considerably less than that of the first strain, which caused the genotype $\mathrm{x}$ bacteria interaction to be significant. Therefore, bacteria application gave better results in Ceysoy variety in terms of total grain weight. Similar to our study, some studies showed that effective agronomic applications such as bacteria caused an increase in the total grain weight of the plant and this increase changed significantly depending on the genotypic capacity (Khoshgoftarmanesh, Schulin, Chaney, Daneshbakhsh, \& Afyuni, 2010). Although the difference in total grain weight between soybean varieties that respond very well to bacterial applications, it was determined that the grain weight increased significantly under optimum growing conditions. In our study, the fact that bacteria application caused higher grain weight and Ceysoy variety caused significantly higher then weight and higher grain weight was obtained in Ceysoy variety than İlksoy variety which supports this situation. In many studies, it has been determined that environmental effects and breeding technique applications, which are highly affected by the genotype $\mathrm{x}$ environment interaction, have a significant effect on the increase and decrease of protein ratio. In addition, it has been emphasized in some studies that the protein ratio is relatively not affected by the environment, but rather shaped under genotypic effect. In our study, the differences between genotypes and bacteria application and control were determined to be insignificant. In this case, it can be concluded that the protein ratio in both varieties is insensitive to fertilizer application or the protein ratio is not affected by either genotypic or environmental effects. In fact, the protein ratio is a product that emerges as a result of metabolic activities that occur as a result of photosynthetic activity and is the basic building block of the plant. Although photosynthetic activities increase and decrease depending on genotypic performance, it is also an element that responds well when breeding techniques and environmental conditions are optimal and close to optimum, so the protein content is higher under optimum conditions and high genotypic conditions (Umar \& Nutrition, 2002). Contrary to the literature, the fact that genotypic and application differences did not occur significantly in our study can be explained by the fact that bacterial application did not have a significant effect on the protein ratio and the difference between genotypes was small. Although the oil rate in the plant responds well to environmental conditions, it mostly occurs depending on genotypic characteristics. The fat ratio, which is the end product of catabolism, causes great differences between genotypes (Schlüter et al., 2012). Therefore, the fact that more fatty acids are obtained from the Ilksoy variety in our study shows this situation. In addition, the oil rate in the plant is not a feature that can change significantly depending on the differences of external factors. 
Therefore, it is less affected by environmental conditions. The small difference between bacteria and control in our study is similar to this situation. In addition, the oil ratio, which changed slightly against environmental conditions, caused the genotype $\mathrm{x}$ bacteria interaction to be insignificant. The oil ratio is an important criterion in determining the commercial value of plants, and it should not be forgotten that a high and edible genotype will have a high commercial spread and preference (Divakara, Upadhyaya, Wani, \& Gowda, 2010). The correlation analysis of yield and quality elements examined in our study is given in Table 3. As seen from the table the plant height and grain weight and grain number and number of grains and number of pods, and again between grain weight and number of grains, a positive and $1 \%$ significant relationship was determined. On the other hand, there was a negative 5\% level significant relationship between oil content and grain number. Considering the degree of representation of the grain weight close to yield, it is a natural result that the number of pods and grains in the plant affects the grain weight. On the other hand, since the oil ratio does not increase directly with plant growth, the oil ratio that does not change much is expected to be negatively related to the number of grains.

Table 1. Variance Analysis Table Showing the Effect of Bacterial Application on Soybean Varieties

\begin{tabular}{|c|c|c|c|c|c|c|c|c|c|}
\hline & \multicolumn{3}{|c|}{ Height of Plant (cm) } & \multicolumn{2}{|c|}{ Number of Pod in Plant } & \multicolumn{2}{|c|}{ Total Grain Number per Plant } & \multicolumn{2}{|c|}{$\begin{array}{l}\text { Total Grain Weight per } \\
\text { Plant (gr) }\end{array}$} \\
\hline & D.F. & Me.Sq. & $\mathbf{F}_{\text {value }}$ & Me.Sq. & $\mathbf{F}_{\text {value }}$ & Me.Sq. & $\mathbf{F}_{\text {value }}$ & Me.Sq. & $\mathbf{F}_{\text {value }}$ \\
\hline Replication & 108 & 83.632 & $0.921 \mathrm{~ns}$ & 639.050 & $1.510 * *$ & 652.537 & $1.261 \mathrm{~ns}$ & 35.560 & $1.095 \mathrm{~ns}$ \\
\hline Genotype & 1 & 32344.083 & $356.045 * *$ & 69.280 & 0.164 ns & 1406,039 & $2.717 \mathrm{~ns}$ & 268.680 & $8.274 * *$ \\
\hline Bacteria & 1 & 273.926 & $3.015 \mathrm{~ns}$ & 21463.021 & $50.706 * *$ & 43480.454 & $84.021 * *$ & 1148.205 & $35.358 * *$ \\
\hline Type xBacteria & 1 & 1372.454 & $15.108 * *$ & 4427.521 & $10.460 * *$ & 1720.009 & $3.324 \mathbf{n s}$ & 136.474 & $4.203^{* *}$ \\
\hline Error & 321 & 90.843 & & 423.283 & & 517.497 & & 32.474 & \\
\hline Total & 431 & 167.285 & & 534.135 & & 661.680 & & 36.618 & \\
\hline \multirow[t]{3}{*}{ CV (\%): } & \multirow{2}{*}{\multicolumn{2}{|c|}{ Protein Ratio (\%) }} & 23.335 & & 42.332 & & 31.406 & & 55.292 \\
\hline & & & & & & \multicolumn{2}{|c|}{ Oil Ratio (\%) } & & \\
\hline & D.F. & Me.Sq. & $\mathbf{F}_{\text {value }}$ & & & D.F. & Me.Sq. & $\overline{F_{\mathrm{va}}}$ & \\
\hline Replication & & 2 & 0.250 & $0.015 \mathrm{~ns}$ & Repetition & & 11 & 0.720 & $0.723 \mathrm{~ns}$ \\
\hline Type & & 1 & 85.333 & $5.078 \mathrm{~ns}$ & Type & & 1 & 114.238 & $114.805 * *$ \\
\hline Bacteria & & 1 & 16.333 & $0.972 \mathrm{~ns}$ & Bacteria & & 1 & 0.065 & $0.066 \mathrm{~ns}$ \\
\hline Genotype x Bacteria & & 1 & 12.000 & $0.714 \mathrm{~ns}$ & Type x Bacteria & & 1 & 1.566 & $1.574 \mathrm{~ns}$ \\
\hline Error & & 6 & 16.806 & & Error & & 33 & 0.995 & \\
\hline Total & & 11 & 19.545 & & Total & & 47 & 3.332 & \\
\hline CV (\%): & & & & 17.333 & & & & & 10,376 \\
\hline
\end{tabular}

**: The mean difference is significant at the 0.01 level.

Table 2. Effect of Bacterial Application on Varieties in terms of Yield and Quality

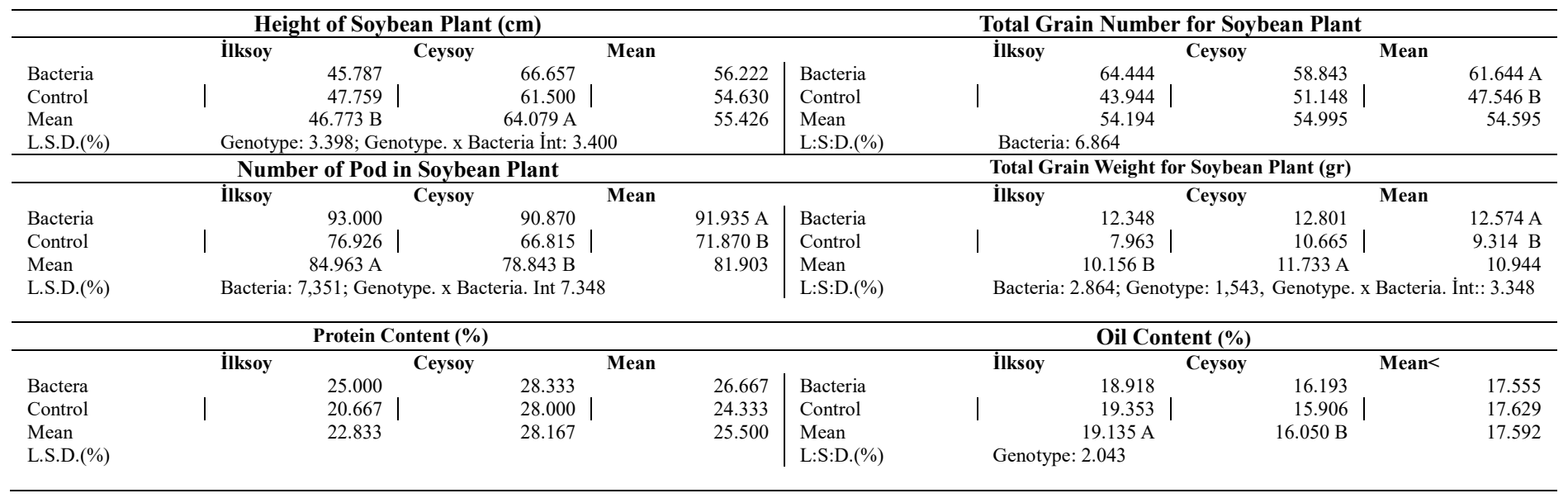

Table 3. Correlation Analysis Between Plant and Quality Factors in Soybean

\begin{tabular}{|c|c|c|c|c|}
\hline & Plant Height & Pod Number & Grain Number & Grain Weight \\
\hline Pod Number & $0,144 \mathrm{~ns}$ & & & \\
\hline Grain Number & $0,371 * *$ & $0,446 * *$ & & \\
\hline Grain Weight & $0,362 * *$ & $0,117 \mathrm{~ns}$ & $0,540 * *$ & \\
\hline Yağ oranı & $0,005 \mathrm{~ns}$ & $-0,081 \mathrm{~ns}$ & $-0,246^{*}$ & $-0,011 \mathrm{~ns}$ \\
\hline
\end{tabular}


Bi-plot analysis included in PCA (Principal Component Analysis) is an important analysis in terms of showing the explainability of the effect amount of the data examined in agricultural research and the variability characteristics of the examined elements. The factor is the reduction analysis with fewer variables. In our study, Bi-plot analysis between plant and quality elements examined in soybean varieties with and without bacteria is shown in Figure 1. As can be seen in the figure, diametrically opposite values were obtained between the yield components obtained from bacteria and control. Except for the oil ratio, the positive reaction of the other factors to the bacterial application can be explained by the fact that these factors are in the same group as the bacteria. Therefore, it can be said that bacterial application has a positive effect on other factors except plant height, protein rate and oil rate and causes an increase. Although decision tree analysis is a widely used analysis in the field of social science, its use in agricultural studies is quite new. The decision tree helps to reveal the effectiveness levels of these elements by making a systematic analysis of the examined elements. It reveals the amount of the dependent variable in the independent variables and its potential to occur, in a hierarchical manner, by revealing the degree of influence of the independent variables that affect the determined dependent variable (Pal \&
Mather, 2003). In our study, the independent variables on grain weight in the plant are given in the decision tree of the city of effect. In the decision tree in the figure, it was determined that the main factor on the grain weight in the plant was the number of grains in the plant. When the number of grains in the plant are more than 135 , the grain weight is 16.121 grams; It was determined that the grain weight of the plant was 14 grams when the number of grains were between 114-136. Likewise, when the number of grains in the plant are between $85-114$, the grain weight is 11.137 grams; If they are less than 85 , the grain weight was determined to be 8.927 grams. It has also been shown that plant height has an effect on grain weight in the decision tree, but this effect has an effect when the number of grains are above 85 . It has been revealed that when the number of grains are between 114136 , the effect of plant height is felt and the grain weight varies between 9.298 and 14.728 grams. Likewise, when the number of grains are between 85 and 114, it has been determined that it affects the plant height and the grain weight varies between 8.540 and 10,468 grams $(\mathrm{R} 2=0.558)$. Therefore, according to the decision tree result, it was determined that the number of grains in the plant and plant height in a hierarchical manner, especially the number of grains in the plant, the number of grains in the plant and the height of the plant affect the grain weight in the plant.

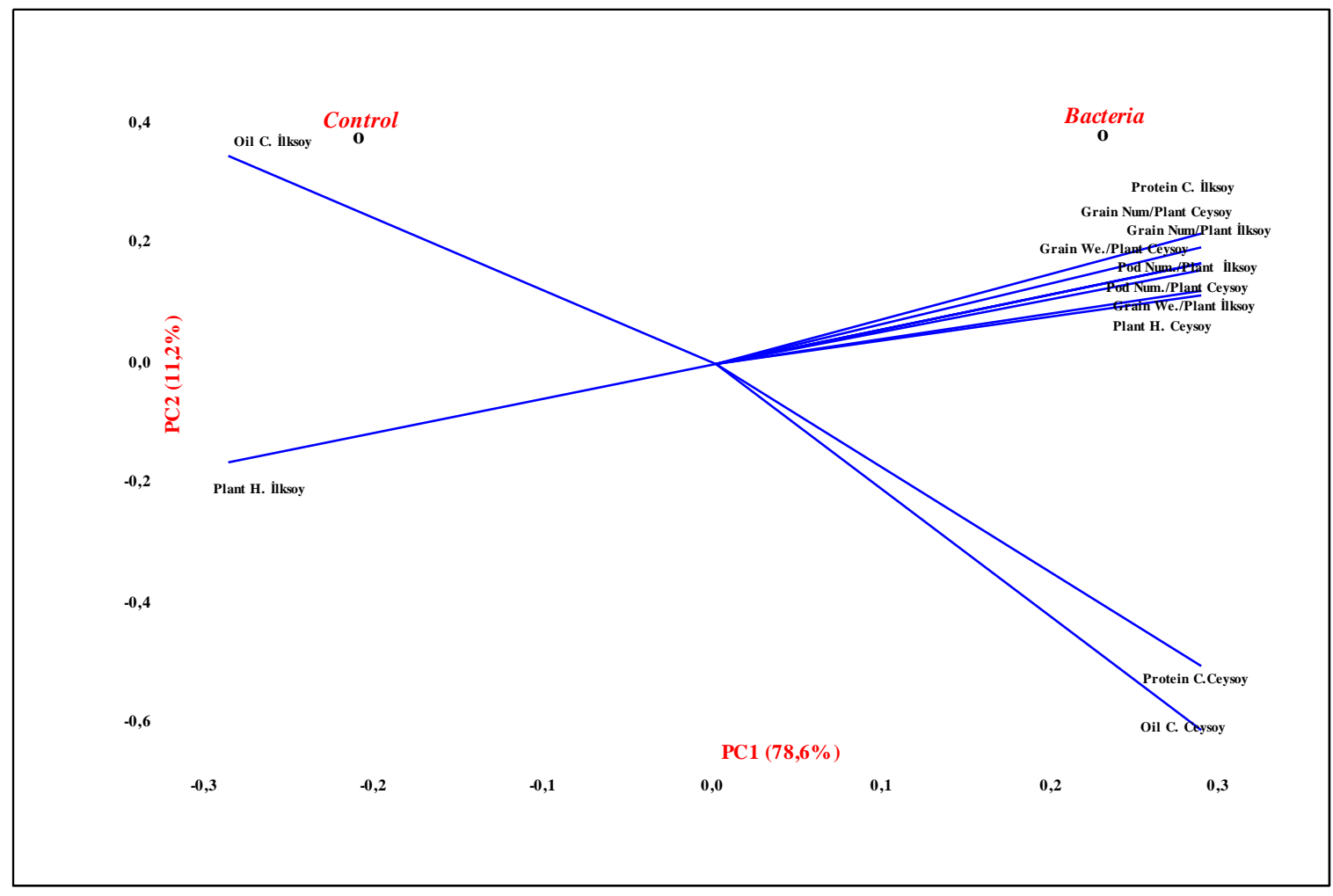

Figure 1. Bi-Plot Analysis of Plant and Quality Elements Examined in Soybean 


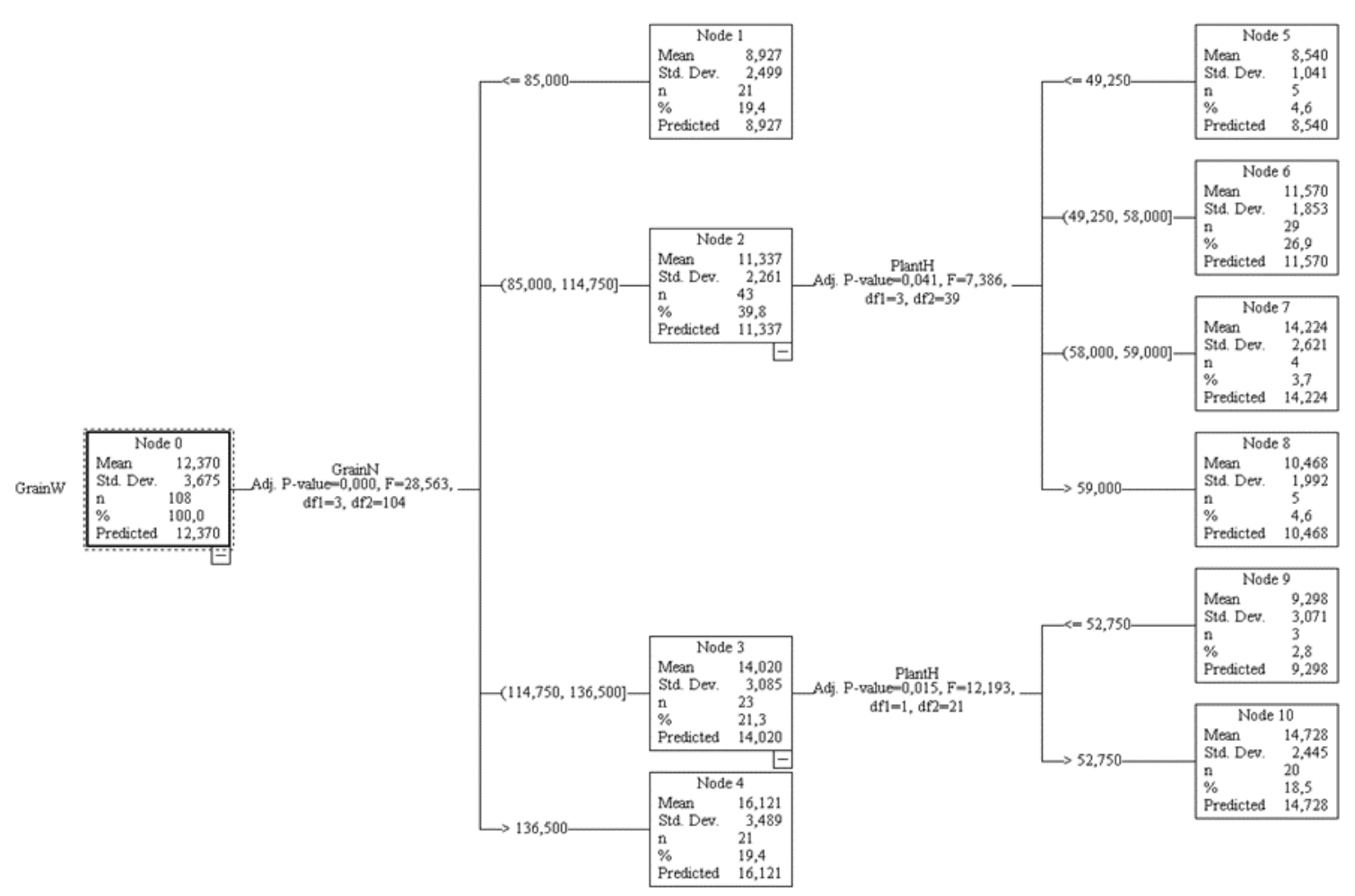

Figure 2. Decision Tree Showing The Effect of Independent Variables on The Dependent Variable in Soybean

\section{Conclusions and Recommendations}

Soybean plant is a promising plant in the world with its high oil content and protein content, which has an important potential in meeting the protein needs of both the oil industry and the food industry, and as a feed plant in livestock. It is a plant that is not sufficiently included in soybean breeding programs and is highly needed to develop high yielding quality varieties resistant to biotic and abiotic stresses. Therefore, the introduction of soybean varieties, which will be revealed through breeding programs to be developed, will both increase the income of the farmer and provide important input to the food industry, and most importantly, will provide added value to the country's economy. In our world, which is getting polluted day by day, the use of artificial inputs such as chemical pesticides, hormones and artificial fertilizers increase efficiency as well as cause environmental pollution to a large extent. Therefore, the use of natural inputs are increasing day by day. The use of this type of inputs will prevent the formation of environmental pollution and will make a significant contribution to the long-term national economies by enabling sustainable agriculture. In this context, microbial fertilizers will accelerate the reduction of environmental pollution and increase sustainable yield. Microbial fertilizer application is also an important application to be included in organic agriculture. With the application of microbial fertilizers, it is highly likely that it will gain momentum in organic agriculture as well as traditional agriculture. In this study, it was determined that the application of bacteria caused an increase in the number of pods in the plant and the number of grains in the plant, which is very effective on the grain weight of the grain yield, which is one of the main elements of the yield, especially considering the bacterial study as the main factor. In addition, although Ceysoy variety was determined as a variety with high yield potential compared to İlksoy variety, it was determined that İlksoy variety with high oil content could be used in oil production in terms of oil yield. Therefore, it has been revealed that there are varieties that can be used to meet the need for roughage in the food industry, oil industry and animal husbandry. According to the results of both correlation and bi-plot analysis, fertilizer application positively affects the number of seeds in the plant, the number of pods and the grain weight, and the number of pods and grains in the plant are effective factors in terms of grain weight, as well as the height of the high variety plant is important and the grain weight in the plant is also affected. In the decision tree analysis, the factors affecting the effective yield factors on the grain weight were determined as the number of seeds per plant and plant height. As a result, while İlksoy and Ceysoy varieties were determined as varieties that can be used in soybean production, it was revealed that they definitely needed microbial fertilizers. Although soybean breeding programs must be developed and increased in number, new varieties must be developed and brought into production. Considering the factors of plant height, number of pods per plant, number of grains per plant and weight in the breeding programs carried out will play an effective and successful role in increasing the effectiveness and success of breeding programs. The PGPR microbial fertilizer seed coating, which has a non-symbiotic effect, fixes the free nitrogen in the air and converts the phosphate in the soil into a form that the plant can take by helping to dissolve some important trace elements such as phosphorus and iron-zinc, which are useful for the plant, by solubilizing the phosphate in the soil in an unsuitable form for the plant increases its importance in nutrition. Although more detailed studies are needed on this subject, it will help to analyze the subject better. 
In our study, soybean (İlksoy and Ceysoy varieties) planting was tried for the first time in Konya Altınekin region, and it is thought that it can be cultivated with factors such as seed coating and its entry into the region as a new alternative agricultural product may contribute to the producers economically.

\section{Acknowledge}

Thanks to Beta Ziraat ve Ticaret Inc. and Konya Food and Agriculture University which has supported the realization of this study.

\section{References}

Altınyüzük, H. (2017). Soya çeşitlerinin Çukurova koşullarında II. ürün olarak verim ve kalite özelliklerinin incelenmesi. Selçuk Üniversitesi Fen Bilimleri Enstitüsü,

Arıoğlu, H. (2007). Yağ Bitkileri Yetiştirme ve Islahı Ders Kitapları Yayın No: A-70. Çukurova Üniversitesi Ziraat Fakültesi Ofset Atölyesi, 204s., Adana.

Baresel, J., Zimmermann, G., \& Reents, H. J. E. (2008). Effects of genotype and environment on $\mathrm{N}$ uptake and $\mathrm{N}$ partition in organically grown winter wheat (Triticum aestivum L.) in Germany. 163(3), 347-354.

Büyük, İ., Soydam-Aydın, S., Aras, S. J. T. B. o. H., \& Biyoloji, E. B. T. H. v. D. (2012). Bitkilerin stres koşullarına verdiği moleküler cevaplar. 69(2).

Divakara, B., Upadhyaya, H., Wani, S., \& Gowda, C. L. J. A. E. (2010). Biology and genetic improvement of Jatropha curcas L.: a review. 87(3), 732-742.

Dobereiner, J., Urquiaga, S., \& Boddey, R. M. (1995). Alternatives for nitrogen nutrition of crops in tropical agriculture. In Nitrogen Economy in Tropical Soils (pp. 338346): Springer.

Fernández, L. A., Zalba, P., Gómez, M. A., \& Sagardoy, M. A. (2007). Phosphate-solubilization activity of bacterial strains in soil and their effect on soybean growth under greenhouse conditions. Biology and Fertility of Soils, 43(6), 805-809.
Ibrahim, E. (2015). Effect of some treatments on seed health and viability of soybean. Plant Pathology Journal, 14(4), 158.

Illmer, P., \& Schinner, F. (1992). Solubilization of inorganic phosphates by microorganisms isolated from forest soils. Soil Biology and Biochemistry, 24(4), 389-395.

Khoshgoftarmanesh, A. H., Schulin, R., Chaney, R. L., Daneshbakhsh, B., \& Afyuni, M. J. A. f. S. D. (2010). Micronutrient-efficient genotypes for crop yield and nutritional quality in sustainable agriculture. A review. 30(1), 83-107.

Kubota, A., Hoshiba, K., \& Bordon, J. (2008). Effect of fertilizer$\mathrm{N}$ application and seed coating with rhizobial inoculants on soybean yield in eastern Paraguay. Revista Brasileira de Ciência do Solo, 32(4), 1627-1633.

Pal, M., \& Mather, P. M. J. R. s. o. e. (2003). An assessment of the effectiveness of decision tree methods for land cover classification. 86(4), 554-565.

Pekşen, E., \& Gülümser, A. J. A. T. B. D. (2005). Bazı Fasulye (Phaseolus vulgaris L.) Genotiplerinde Verim ve Verim Unsurları Arasındaki İlişkiler ve Path Analizi. 20(3), 82-87.

Peoples, M. B., \& Craswell, E. T. (1992). Biological nitrogen fixation: investments, expectations and actual contributions to agriculture. Plant and soil, 141(1-2), 13-39.

Peske, F. B., Baudet, L., \& Peske, E. (2009). Produtividade de plantas de soja provenientes de sementes tratadas com fósforo. Revista Brasileira de Sementes, 31(1).

Rodríguez, H., \& Fraga, R. (1999). Phosphate solubilizing bacteria and their role in plant growth promotion. Biotechnology advances, 17(4-5), 319-339.

Schlüter, U., Mascher, M., Colmsee, C., Scholz, U., Bräutigam, A., Fahnenstich, H., \& Sonnewald, U. J. P. P. (2012). Maize source leaf adaptation to nitrogen deficiency affects not only nitrogen and carbon metabolism but also control of phosphate homeostasis. 160(3), 1384-1406.

Umar, S., \& Nutrition, M. J. J. o. P. (2002). Genotypic differences in yield and quality of groundnut as affected by potassium nutrition under erratic rainfall conditions. 25(7), 1549-1562. 